\title{
CHILD ABUSE DAN KEAMANAN LINGKUNGAN ANAK DALAM MENYONGSONG BONUS DEMOGRAFI 2025-2030
}

\author{
Rabiah Al Adawiah \\ Universitas Bhayangkara Jakarta Raya \\ rabiah74adawiah@gmail.com
}

\begin{tabular}{|c|c|c|}
\hline Naskah diterima: & Revisi: & Naskah disetujui: \\
$26 / 4 / 2019$ & $16 / 5 / 2019$ & $16 / 5 / 2019$ \\
\hline
\end{tabular}

\begin{abstract}
Abstrak
Anak-anak sangat penting karena mereka adalah nasib potensial dari suatu generasi atau bangsa di masa depan. Saat ini, sepertiga penduduk Indonesia adalah anak-anak dan di masa depan (2025-2030), Indonesia akan memiliki bonus demografi. Pada saat yang sama, berbagai kasus dialami oleh anak-anak Indonesia, seperti perdagangan, penindasan, eksploitasi seksual, makanan dan makanan ringan yang mengandung bahan berbahaya, pedagang dan pengguna narkoba, kekerasan fisik dan psikis di lingkungan dan sekolah. Ironisnya, sekolah di mana anak-anak mendapatkan pendidikan tidak terlepas dari tindakan kekerasan dan pelanggaran hak-hak anak lainnya. Kasus anak-anak yang melibatkan guru sebagai pelaku masih terjadi. Para guru melakukan hal-hal yang tidak terpuji sebagai orang tua anak-anak di sekolah. Jika kita merefleksikan berbagai kasus yang dialami oleh anakanak saat ini, maka 'bonus demografi' di masa depan tidak akan menjadi lebih baik. Mengamati berbagai kasus pelecehan anak (kekerasan, kesehatan, penggunaan narkoba dan sebagainya), perlu untuk menciptakan lingkungan yang aman, nyaman dan sehat untuk anakanak. Negara / pemerintah harus memastikan bahwa hak-hak anak terpenuhi (mendapatkan perlindungan dari kekerasan, kesehatan, hingga hak untuk bertahan hidup). Penulisan ini didasarkan pada hasil analisis yang menggunakan metode analisis deskriptif kualitatif dengan mengumpulkan berbagai macam literatur relevan, yang memiliki keterkaitan dengan permasalahan child abuse di Indonesia, kemudian merumuskan suatu pemecahan masalah yang dihadapi.
\end{abstract}

Kata kunci: kekerasan anak, rasa aman, perlindungan anak, Napza, pemerintah.

\begin{abstract}
Children are very important because they are the potential fate of a generation or nation in the future. Today, one third of Indonesia's population is children and in the future (20252030), Indonesia will have a demographic bonus. At the same time, various cases experienced by Indonesian children, such as trafficking, bullying, sexual exploitation, food and snacks containing harmful ingredients, dealers and drug users, physical and psychic violence at neighborhood and the school. Ironically, schools where the children get education don't be detached from acts of violence and other infringement of children's rights. Cases of children involving teachers as perpetrators still occur. The teachers do uncommendable things as parents of children in school. If we reflect on the various cases experienced by children at this time, then the 'demographic bonus' in the future will not
\end{abstract}


become better. Observing various cases of child abuse (violence, health, drug use and so on), it is necessary to create a safe, comfortable and healthy environment for children. The state/ government must ensure that the children's rights are fulfilled (getting protection from violence, health, until the rights to survival). This paper is based on the results of the analysis using qualitative descriptive analysis method by collecting various kinds of relevant literature, which have relevance to the problem of child abuse in Indonesia, then formulate a problem solving that is faced.

Keywords: child abuse, Secure, child protection, Government.

\section{PENDAHULUAN}

\section{A. Latar Belakang Masalah}

Bonus demografi adalah kondisi dimana penduduk usia produktif jauh melebihi penduduk tidak produktif yang kemudian menyebabkan turunnya rasio harus ditanggung oleh penduduk produktif terhadap penduduk tidak produktif mencapai titik terendah. ${ }^{1}$ Berdasarkan hasil Proyeksi Penduduk tahun 2010-2035, Indonesia akan mengalami bonus demografi, dimana rasio ketergantungan penduduk sebesar 48,6. Angka ketergantungan penduduk Indonesia akan terus menurun sampai 2020. Puncak bonus demografi akan terjadi pada tahun 2025-2030. Bila merujuk jumlah anak Indonesia (usia 0-17) saat ini sebanyak 87 juta jiwa atau atau hampir sepertiga penduduk Indonesia (Data KPAI, 2018), maka anakanak inilah yang akan menjadi bagian dari bonus demografi ke depan.

Permasalahannya adalah anak-anak yang merupakan generasi masa depan tersebut masih menghadapi berbagai kasus untuk mendapatkan hak-hak anak saat ini, seperti hak hidup, hak tumbuh dan berkembang, hak perlindungan, dan hak partisipasi. Berbagai masalah tersebut seperti, menjadi korban dari kasus kekerasan fisik hingga psikis, trafficking, bullying, eksploitasi seksual, jajanan makanan yang mengandung zat berbahaya, di lingkungan tempat tinggal hingga lingkungan sekolah dan masih banyak lagi kasus-kasus child abuse lainnya.

Darurat perlindungan anak menjadi suatu fenomena pada tahun 2015, dimana banyak kasus-kasus anak yang mencengangkan masyarakat dan pemerintah Indonesia, bahkan dunia juga turun melihat kondisi perlindungan anak di Indonesia, sebagai salah satu perlindungan anak yang cukup rawan. Memasuki tahun 2018, selama dua pekan sudah marak terjadi kasus kekerasan anak. Parahnya, kasus-kasus kekerasan tersebut mayoritas terjadi di ranah privat

\footnotetext{
${ }^{1}$ Adioetomo, Sri Moertiningsih, dkk. 100 Tahun Demografi Indonesia: Mengubah Nasib menjadi Harapan. Cetakan Kedua. (Jakarta, BKKBN dan LDFEUI, 2010)
} 
atau di dalam rumahnya sendiri. Contoh, di bulan Januari, seorang ibu di Palembang rela menjual anaknya yang berusia 2,5 tahun demi beli Narkoba jenis sabu. ${ }^{2}$ Pada bulan yang sama, seorang ibu membunuh tiga anaknya di dalam kamar mandi rumahnya, di Jombang. ${ }^{3}$ Pada bulan februari, seorang anak berusia 1,5 tahun meninggal di Bekasi dengan kondisi luka lebam di beberapa bagian tubuh diduga bekas siksaan orangtuanya. ${ }^{4}$

Child abuse termasuk semua bentuk perlakuan menyakitkan baik fisik, seksual maupun emosional yang dilakukan orang tua atau orang lain dalam konteks hubungan tanggung jawab atau kekuasaan. Child abuse atau sering diartikan sederhana "kekerasan terhadap anak" merupakan keadaan yang sering kita jumpai pada kehidupan sehari-hari, fenomena gunung es berlaku pada keadaan tersebut, data pasti mengenai child abuse sulit diperoleh. Data yang dihimpun oleh Komisi Perlindungan Anak Indonesia (KPAI) merupakan data laporan atau pengaduan sehingga data tersebut belum termasuk kasus-kasus yang tidak dilaporkan termasuk data kekerasan anak yang tidak terungkap dalam lingkup rumah tangga. Tindak kekerasan ini disebut hidden crime (kejahatan yang tersembunyi) karena baik pelaku maupun korban berusaha untuk merahasiakan perbuatan tersebut dari pandangan publik, kadang juga disebut domestic violence (kekerasan domestik). ${ }^{5}$

Faktor resiko baik pada anak, orang tua/situasi keluarga maupun masyarakat/sosial mempunyai hubungan dengan dugaan kekerasan pada anak. ${ }^{6}$ Berbagai kasus yang melibatkan anak memberikan dampak terhadap generasi masa depan Indonesia. Baik buruknya masa depan bangsa tergantung pula pada baik buruknya kondisi anak saat ini. ${ }^{7}$ Sehingga meskipun bonus demografi secara kuantitas terpenuhi namun tantangannya adalah problem kualitas generasi yang akan mengisi masa-masa tersebut. Bila bercermin pada berbagai kasus yang melibatkan anak, maka bisa jadi 'bonus demografi' ke depan tidak lagi bermakna lebih baik.

\footnotetext{
${ }^{2}$ Berita ini dapat ditelusuri di media online, seperti di https://news.detik.com/berita/d-3819079/miris-ibukandung-di-palembang-jual-bayi-rp-20-juta-untuk-beli-sabu

${ }^{3}$ Berita ini dapat ditelusuri di media online, seperti di https://news.detik.com/berita-jawa-timur/d-3830088/inikesimpulan-polisi-usai-periksa-ibu-yang-bunuh-3-anaknya?_ga=2.224627359.404968860.1531111802619765380.1521553471

${ }^{4}$ Berita ini dapat ditelusuri di media online, seperti di https://megapolitan.kompas.com/read/2018/02/05/ 05513961/anak-15-tahun-di-bekasi-meninggal-diduga-dianiaya-orangtua.

${ }^{5}$ Moerti Hadiati Soeroso, Kekerasan Dalam Rumah Tangga Dalam Perspektif Yuridis Viktimologis, (Jakarta, Sinar Grafika, 2010), 1.

${ }^{6}$ Daisy Widiastuti, Rini Sekartini, Sari Pediatri, "Deteksi Dini, Faktor Risiko, dan Dampak Perlakuan Salah Terhadap Anak," Sari Pediatri, Vol. 7, No. 2, (September, 2005) : 105.

${ }^{7}$ M. Nasir Djamil, Anak Bukan Untuk Dihukum (Jakarta, Sinar Grafika, 2013), 11
} 
Anak adalah generasi penerus yang akan datang. Anak merupakan cerminan sikap hidup bangsa dan penentu perkembangan bangsa tersebut. ${ }^{8}$ Yang dimaksud dengan anakanak adalah rentang usia 0-17 tahun. Kategori anak ini mengacu pada Undang-undang no. 23 tahun 2002 tentang Perlindungan Anak pasal 1 ayat (1), “Anak adalah seseorang yang belum berusia 18 (delapan belas) tahun, termasuk anak yang masih dalam kandungan."

Adapun keamanan lingkungan adalah hal yang sangat penting karena lingkungan merupakan tempat anak hidup, tumbuh dan berkembang. Anak sangat rentan dipengaruhi oleh lingkungan dimana ia berada. Anak memiliki karakteristik tertentu yang khas dan tidak sama dengan orang dewasa, mereka selalu aktif, dinamis, antusias dan ingin tahu terhadap apa yang dilihat, didengar, serta dirasakan mereka seolah-olah tidak pernah berhenti bereksplorasi dan belajar. ${ }^{9}$ Secara fisik, psikis, kognitif maupun sifat yang melekat pada anak-anak sangat rentan terhadap ancaman yang dapat membahayakan dirinya. Apalagi bila lingkungan tempat anak berada tidak lagi aman karena adanya perlakuan kekerasan, eksploitasi, penculikan, dan lainnya.

Oleh karena itu, anak-anak berhak dan wajib mendapat perlindungan. Anak merupakan potensi nasib suatu generasi atau bangsa di masa mendatang. Anak harus diberikan kesempatan sebaik-baiknya memanfaatkan lingkungannya untuk tumbuh dan berkembang, seperti mendapatkan pengasuhan yang baik, pendidikan yang layak, serta jaminan kesehatan.

\section{B. Tujuan dan Metode}

Berdasarkan uraian di atas, maka penulisan ini hendak menguraikan bagaimana keamanan lingkungan berpengaruh terhadap terjadinya kasus-kasus kekerasan terhadap anak (child abuse). Tujuan penulisan ini selain memberikan gambaran mengenai kasus kekerasan anak yang terjadi di Indonesia, juga menawarkan gagasan bagaimana menciptakan lingkungan yang aman dan nyaman untuk perlindungan anak dalam menyongsong bonus demografi 2025-2030.

Penulisan ini didasarkan pada hasil analisis yang menggunakan metode analisis deskriptif kualitatif berbasis kajian berbagai macam literatur relevan, baik jurnal, buku, proceeding maupun working paper, yang memiliki keterkaitan dengan permasalahan child

\footnotetext{
${ }^{8}$ Wagiati Sutedjo, Hukum Pidana Anak (Bandung, Refika Aditama, 2010), 5.

${ }^{9}$ Yuliani Nuraini dan Sujiono, Konsep Dasar Pendidikan Anak Usia Dini (Jakarta, PT Indeks, 2009), 6.
} 
abuse dan lingkungan terjadinya, kemudian merumuskan suatu pemecahan masalah yang dihadapi.

\section{Kerangka Teoritik dan Penelitian Terdahulu}

Child abuse atau sering diartikan dengan kekerasan anak atau penganiayaan anak atau penderaan anak atau perlakuan salah terhadap anak. Secara teoritis, child abuse adalah semua bentuk perlakuan menyakitkan secara fisik ataupun emosional, penyalahgunaan seksual, pelalaian, eksploitasi komersial atau eksploitasi lain, yang mengakibatkan cedera/kerugian nyata ataupun potensial terhadap kesehatan anak, kelangsungan hidup anak, tumbuh kembang anak, atau martabat anak, yang dilakukan dalam konteks hubungan tanggung jawab, kepercayaan, atau kekuasaan. ${ }^{10}$ Henry Kempe dalam Suyanto (2010) menyebut kasus-kasus penelantaran dan penganiayaan yang dialami anak - anak dengan istilah Batered Child Syndrome, yaitu setiap keadaan yang disebabkan kurangnya perawatan dan perlindungan terhadap anak oleh orangtua atau pengasuh lain. Disini yang diartikan sebagai tindak kekerasan terhadap anak tidak hanya luka berat saja, tetapi termasuk juga luka memar atau membengkak sekalipun dan diikuti kegagalan anak untuk berkembang baik secara fisik maupun intelektualnya. ${ }^{11}$

Menurut Suyanto bahwa kekerasan terhadap anak dapat didefinisikan sebagai peristiwa pelukaan fisik, mental, atau seksual yang umumnya dilakukan oleh orang - orang yang memiliki tanggung jawab terhadap kesejahteraan anak, yang mana itu semua diindikasikan dengan kerugian dan ancaman terhadap kesehatan dan kesejahteraan anak. Terdapat lima bentuk kekerasan terhadap anak sebagaimana diklasifikasikan oleh Suyanto, yaitu : (1) kekerasan fisik, bentuk ini paling mudah dikenali. Korban kekerasan jenis ini biasanya tampak secara langsung pada fisik korban seperti; luka memar, berdarah, dan bentuk lain yang kondisinya lebih berat. (2) Kekerasan Psikis, bentuk ini tidak begitu mudah dikenali. Wujud dari kekerasan ini bisa berupa kata - kata kasar, ejekan, mempermalukan, dan sebagainya. Dampak kekerasan jenis ini akan berpengaruh pada situasi perasaan yang tidak aman dan nyaman, minder, lemah dalam mengambil keputusan, dan bahkan menurunnya harga diri serta martabat korban. (3) Kekerasan seksual, termasuk dalam kategori ini adalah segala tindakan yang mencul dalam bentuk paksaan untuk melakukan hubungan seksual. (4) Kekerasan Ekonomi, kekerasan jenis ini sangat sering terjadi di

\footnotetext{
${ }^{10}$ M Fakih, penyunting. Buku Panduan Pelatihan Deteksi Dini Dan Penatalaksanaan Korban Child Abuse And Neglect. (Jakarta: IDI-UNICEF, 2003), 1-77.

${ }^{11}$ Bagong Suyanto, Masalah Sosial Anak (Jakarta: Kencana, 2010), 27
} 
lingkungan keluaraga. Pada anak, kekerasan ini sering terjadi ketika orang tua memaksa anak yang masih usia di bawah umur untuk dapat memebrikan kontribusi ekonomi keluarga, sehingga fenomena penjualan anak, pengamen jalanan, pengemis anak, dan lain - lain kian merebak. (5) Kekerasan anak secara sosial, kekerasan anak jenis ini mencakup penelantaran anak dan eksploitasi anak. Penelantaran anak adalah sikap dan perlakuan orangtua yang tidak memberikan perhatian yang layak terhadap proses tumbuh kembang anak. ${ }^{12}$

Nilai anak dalam masyarakat sangat beragam dan mengalami pergeseran sesuai lingkungan sosial budaya masyarakat setempat. Secara umum dalam rentang sejarah kehidupan manusia ada dua jenis nilai anak yang dominan dalam masyarakat kita. Pertama, anak sebagai nilai sejarah, yang berkembang dalam keluarga raja atau elite penguasa, yang dalam perkembangannya diikuti oleh komunitas penyangga keberadaan elite penguasa tersebut, yaitu keluarga priayi. Persektif anak sebagai nilai sejarah berarti anak harus meneruskan sejarah dinasti atau sejarah garis keturunan. ${ }^{13}$

Kedua, anak sebagai nilai ekonomi. Nilai tumbuh pada lapisan masyarakat umum dengan komunitas petani, pedagang, buruh, nelayan dan sebagainya. Anak dipandang sebagai nilai ekonomi, karena dari anak-anak akan membantu menyangga kehidupan ekonomi keluarga, apabila orangtua mereka sudah beranjak tua. Karena nilai anak adalah pada nilai ekonomi, anak diangap bermanfaat kalau membantu meringankan orangtua, seperti merumput, mencari kayu bakar, mengambil air di sumur, tetapi juga bekerja di sektor formal. Tidak jarang mereka bekerja pada area yang membahayakan dan membunuh masa depan anak-anak yang disebut sebagai jenis-jenis pekerjaan terburuk. Karena nilai anak adalah pada nilai ekonomi, anak dianggap bermanfaat kalau memberikan sumbangan kepada keluarga. ${ }^{14}$

Anak dengan mudah menjadi korban kekerasan karena berada pada posisi yang lemah. Selain lemah fisik, kepolosan dan keluguan pada anak semakin memuluskan jalan pelaku untuk melancarkan aksinya, sehingga banyak anak yang menjadi korban. Saat ini kekerasan anak di Indonesia cukup tinggi dan bahkan riilnya, jumlah kasus tersebut lebih banyak dari pada yang terungkap ke permukaan. Hal itu karena masih banyak orang tua yang tak mau melaporkan kasus kekerasan yang dialami oleh anaknya pada pihak yang berwajib atau lembaga perlindungan anak, karena malu atau dapat menimbulkan aib bagi mereka.

\footnotetext{
12 Ibid., 28-29

13 Hadi Supeno, Kriminalisasi Anak Tawaran Gagasan Radikal Peradilan Anak Terhadap Pemidanaan, (Jakarta: Gramedia Pustaka, 2010), 19-21.

${ }^{14}$ Ibid., 22-23.
} 
Kesadaran yang rendah dalam melaporkan kasus anak menjadi persoalan tersendiri karena jika dibiarkan terus tanpa ada antisipasi yang jelas maka jumlah kasus kekerasan terhadap anak akan semakin bertambah. Apabila generasi penerus bangsa, yaitu anak, sudah tidak diperhatikan lagi oleh masyarakat dengan baik, maka perkembangan kehidupan di masyarakat akan mengalami mengalami kemunduran dengan pesat. ${ }^{15}$ Akibatnya, mewujudkan generasi bangsa yang berkualitas terutama dalam memanfaatkan bonus demografi ke depan hanya angan-angan belaka.

Anak-anak tumbuh dan berkembang dengan baik di lingkungannya bila mereka menerima segala kebutuhannya dengan optimal. Jika salah satu kebutuhan baik asuh, asih, maupun asah tidak terpenuhi maka akan terjadi kepincangan dalam tumbuh kembang mereka. Dampak yang terjadi dapat secara langsung maupun tidak langsung atau dampak jangka pendek dan dampak jangka panjang. ${ }^{16}$

Pertumbuhan dan perkembangan anak yang mengalami child abuse, pada umumnya lebih lambat dari pada anak yang normal, yaitu berdampak langsung terhadap kejadian child abuse 5\% mengalami kematian, 25\% mengalami komplikasi serius seperi patah tulang, luka bakar, cacat menetap. Selain itu, terjadi kerusakan menetap pada susunan saraf yang dapat mengakibatkan retardasi mental, masalah belajar/kesulitan belajar, buta, tuli, masalah dalam perkembangan motor/ pergerakan kasar dan halus, kejadian kejang, ataksia, ataupun hidrosefalus. Adapun dampak terhadap pertumbuhan fisik anak pada umumnya kurang dari anak-anak sebayanya, tetapi Oates $d k k$ pada tahun 1984 mengatakan bahwa tidak ada perbedaan yang bermakna dalam tinggi badan dan berat dengan anak normal. ${ }^{17}$

Sementara dampaknya terhadap perkembangan kejiwaan juga mengalami gangguan yaitu:

Pertama, kecerdasan. Berbagai penelitian melaporkan terdapat keterlambatan dalam perkembangan kognitif, bahasa, membaca, dan motorik. Retardasi mental dapat diakibatkan trauma langsung pada kepala, jugakarena malnutrisi. Anak juga kurangmendapat stimulasi adekuat karena gangguan emosi. ${ }^{18}$

Kedua, emosi. Masalah yang sering dijumpai adalah gangguan emosi, kesulitan belajar/sekolah, kesulitan dalam mengadakan hubungan dengan teman, kehilangan

\footnotetext{
${ }^{15}$ Laurensius Arliman S. "Partisipasi Masyarakat di dalam Perlindungan Anak yang Berkelanjutan sebagai Bentuk Kesadaran Hukum," Jurnal Ilmu Hukum, Volume 3, Nomor 2, (2016) : 323.

${ }^{16}$ Daisy Widiastuti, Rini Sekartini, Sari Pediatri. "Deteksi Dini, Faktor Risiko, dan Dampak Perlakuan Salah Terhadap Anak," Sari Pediatri, Vol. 7, No. 2, (September, 2005) : 110.

${ }^{17}$ Ibid., 110.

${ }^{18}$ Ibid., 111.
} 
kepercayaan diri, fobia cemas, dan dapat juga terjadi pseudomaturitas emosi. Beberapa anak menjadi agresif atau bermusuhan dengan orang dewasa, atau menarik diri/menjauhi pergaulan. Anak suka mengompol, hiperaktif, perilaku aneh, kesulitan belajar, gagal sekolah, sulit tidur, temper tantrum. ${ }^{19}$

Ketiga, konsep diri. Anak yang mendapat kejadianchild abuse merasa dirinya jelek, tidak dicintai,tidak dikehendaki, muram dan tidak bahagia,tidak mampu menyenangi aktifitas danmelakukan percobaan bunuh diri. ${ }^{20}$

Keempat, agresif. Anak yang mendapat kejadian childabuse lebih agresif terhadap teman sebaya. Sering tindakan agresif tersebut menirutindakan orang tua mereka atau mengalihkan perasaan agaresif kepada teman sebayanyasebagai hasil kurangnya konsep diri. $^{21}$

Kelima, hubungan sosial. Pada anak-anak tersebut kurang dapat bergaul dengan teman sebaya atau dengan orang dewasa, misalnya melempari batu, perbuatan kriminal lainnya. ${ }^{22}$

Keenam, akibat dari sexual abuse. tanda akibat trauma atau infeksi lokal, seperti nyeri perineal, sekret vagina, nyeri dan perdarahan anus; Tanda gangguan emosi, misalnya konsentrasi kurang, enuresis, enkopresis, anoreksia dan perubahan tingkah laku, kurang percaya diri, sering menyakiti diri sendiri, dan sering mencoba bunuh diri; Tingkah laku atau pengetahuan seksual anak yang tidak sesuai dengan umurnya. ${ }^{23}$

\section{Payung Hukum}

Dari perspektif norma, Indonesia dapat dikategorikan sebagai negara yang memiliki komitmen besar bagi perlindungan anak. Komitmen tersebut bukan hanya termaktub dalam undang-undang semata, namun secara eksplisit tercantum dalam Undang-Undang Dasar Negara Republik Indonesia Tahun 1945. Pasal 28 B ayat (2) menegaskan bahwa "Setiap anak berhak atas kelangsungan hidup, tumbuh, dan berkembang serta berhak atas perlindungan dari kekerasan dan diskriminasi". Konstitusi tersebut menegaskan bahwa negara memastikan tak boleh ada anak di manapun berada tidak mendapatkan perlindungan.

Dalam UU No 35 Tahun 2014 Tentang Perubahan Atas Undang-Undang Nomor 23 Tahun 2002 Tentang Perlindungan Anak, pasal 1 butir 2 disebutkan "Perlindungan Anak

\footnotetext{
${ }^{19}$ Ibid., 111.

${ }^{20} \mathrm{Ibid}$.

${ }^{21}$ Ibid.

${ }^{22} \mathrm{Ibid}$.

${ }^{23} \mathrm{Ibid}$.
} 
adalah segala kegiatan untuk menjamin dan melindungi anak dan hak-haknya agar dapat hidup, tumbuh, berkembang, dan berpartisipasi secara optimal sesuai dengan harkat dan martabat kemanusiaan, serta mendapat perlindungan dari kekerasan dan diskriminasi."

Perlindungan anak merupakan pertanggungjawaban orang tua, keluarga, masyarakat, pemerintah dan negara yang merupakan rangkaian kegiatan yang dilaksanakan secara terus menerus demi terlindunginya hak-hak anak. ${ }^{24}$ Perlindungan anak terkait erat dengan lima pilar yakni, orang tua, keluarga, masyarakat, pemerintah, pemerintah daerah dan negara. Kelimanya memiliki keterkaitan satu sama lain sebagai penyelenggara perlindungan anak. ${ }^{25}$ Mengenai hal ini sesungguhnya telah diatur dalam Pasal 20 UU No 35 Tahun 2014 dengan menyebutkan bahwa negara, pemerintah, pemerintah daerah, masyarakat, keluarga, dan orang tua atau wali berkewajiban dan bertanggung jawab terhadap penyelenggaraan perlindungan anak.

Pasal 23 dan Pasal 24 UU No 35 Tahun 2014 mengatur mengenai jaminan negara dan pemerintah atas penyelenggaraan perlindungan anak. Negara dan pemerintah menjamin perlindungan, pemeliharaan dan kesejahteraan anak dengan memperhatikan hak dan kewajiban orang tua, wali, atau orang lain yang secara hukum bertanggungjawab terhadap anak. Negara dan pemerintah juga menjamin anak untuk menggunakan haknya dalam menyampaikan pendapat sesuai dengan usia dan tingkat kecerdasan anak. Jaminan yang diberikan oleh negara dan pemerintah tersebut diikuti pula dengan pengawasan dalam penyelenggaraan perlindungan anak.

Pemerintah telah menerbitkan perangkat hukum dan kebijakan yang cukup progresif serta meratifikasi berbagai perjanjian internasional terkait anak. Berikut adalah daftar perangkat hukum yang diadopsi dari tahun 1990-2015.

\begin{tabular}{|l|l|}
\hline Tahun & Kebijakan \\
\hline $1990-1995$ & $\bullet$ Ratifikasi Konvensi Hak Anak PBB di tahun 1990 \\
\hline $1996-2000$ & $\begin{array}{l}\bullet \text { Undang-Undang No. 39 Tahun } 1999 \text { tentang Hak Asasi } \\
\text { Manusia }\end{array}$ \\
\hline 2001-2005 & $\begin{array}{l}\text { Undang-Undang No. 23 Tahun } 2002 \text { tentang Perlindungan } \\
\text { Anak }\end{array}$ \\
\hline
\end{tabular}

\footnotetext{
${ }^{24}$ Ahmad Kamil dan Fauzan, Hukum Perlindungan dan Pengangkatan Anak di Indonesia (Jakarta: PT Raja Grafindo Persada, 2008), 5

${ }^{25}$ Rini Fitriani, "Peranan Penyelenggara Perlindungan Anak Dalam Melindungi Dan Memenuhi Hak-Hak Anak," Jurnal Hukum Samudra Keadilan, Volume 11, Nomor 2, (Juli-Desember 2016) : 251
} 


\begin{tabular}{|c|c|}
\hline & $\begin{array}{l}\text { - Undang-Undang No. } 20 \text { Tahun } 2003 \text { tentang Sistem } \\
\text { Pendidikan Nasional } \\
\text { - Undang-Undang No. } 23 \text { Tahun } 2004 \text { tentang Penghapusan } \\
\text { Kekerasan Terhadap Rumah Tangga }\end{array}$ \\
\hline 2006- & $\begin{array}{l}\text { - Undang-Undang No. } 12 \text { Tahun } 2006 \text { tentang } \\
\text { Kewarganegaraan RI } \\
\text { - Undang-Undang No. } 17 \text { Tahun } 2007 \text { tentang Rencana } \\
\text { Pembangunan Jangka Panjang Nasional 2005-2025 } \\
\text { - Undang-Undang No. } 21 \text { Tahun } 2007 \text { tentang Pemberantasan } \\
\text { Tindak Pidana Perdagangan Orang } \\
\text { - Undang-Undang No. } 40 \text { Tahun } 2008 \text { tentang Penghapusan } \\
\text { Diskriminasi Ras dan Etnis } \\
\text { - Peraturan Pemerintah No. } 47 \text { Tahun } 2008 \text { tentang Wajib } \\
\text { Belajar } \\
\text { - Undang-Undang No. } 44 \text { Tahun } 2008 \text { tentang Pornografi }\end{array}$ \\
\hline 2011-2015 & $\begin{array}{l}\text { - Undang-Undang No. } 24 \text { Tahun } 2011 \text { tentang Badan } \\
\text { Penyelenggara Jaminan Sosial } \\
\text { - Ratifikasi Konvensi Hak-Hak Penyandang Disabilitas di } \\
\text { Tahun } 2011 \\
\text { - Undang-Undang No. } 11 \text { Tahun } 2011 \text { tentang Sistem Peradilan } \\
\text { Anak } \\
\text { - Undang-Undang No. } 7 \text { Tahun } 2012 \text { tentang Penanganan } \\
\text { Konflik Sosial } \\
\text { - Undang-Undang No. } 24 \text { Tahun } 2013 \text { tentang Administrasi } \\
\text { Kependudukan } \\
\text { - Ratifikasi Protokol Opsional Konvensi Hak-Hak Anak tentang } \\
\text { Keterlibatan Anak di Konflik Bersenjata di Tahun } 2012 \\
\text { - Ratifikasi Protokol Opsional Konvensi Hak-Hak Anak tentang } \\
\text { Perdagangan Anak, Prostitusi Anak, dan Pornografi Anak di } \\
\text { Tahun } 2012 \\
\text { - Ratifikasi Konvensi Internasional Perlindungan Hak-Hak } \\
\text { Tenaga Kerja Migran dan Keluarganya di Tahun } 2012\end{array}$ \\
\hline
\end{tabular}


- Undang-Undang No. 35 Tahun 2014 tentang Perlindungan Anak (Revisi terhadap Undang-Undang Perlindungan Anak No. 23 Tahun 2002)

Sumber: Kemen PPPA, Strategi Nasional Penghapusan Kekerasan Terhadap Anak 20162020

Dapat disimpulkan bahwa dari perspektif regulasi (payung hukum) tidak kurang perhatian pemerintah untuk terus berupaya memberikan perlindungan bagi seluruh anak Indonesia. Bahkan secara kelembagaan, perlindungan hak-hak anak tidak saja ditugaskan pada satu lembaga pemerintah seperti Kementerian Pemberdayaan Perempuan dan Perlindungan Anak, tetapi juga terdapat Komisi Perlindungan Anak Indonesia (KPAI) yang tugasnya melakukan sosialisasi seluruh ketentuan peraturan perundang-undangan yang berkaitan dengan perlindungan anak, mengumpulkan data dan informasi, menerima pengaduan masyarakat, melakukan penelaahan, pemantauan, evaluasi, dan pengawasan terhadap penyelenggaraan perlindungan anak; memberikan laporan, saran, masukan, dan pertimbangan kepada Presiden dalam rangka perlindungan anak.

Terkait upaya menciptakan terwujudnya pendidikan yang aman dan nyaman bagi seluruh anak Indonesia, komitmen pemerintah dapat dilihat dari regulasi yang diterbitkan oleh Kementerian Pendidikan dan Kebudayaan (Kemendikbud) dalam rentang tahun 20152018. Regulasi tersebut berupa Peraturan Menteri Pendidikan dan Kebudayaan (Permendikbud), yaitu Permendikbud No. 23 Tahun 2015 tentang Penumbuhan Budi Pekerti; Permendikbud No. 64 Tahun 2015 tentang Kawasan Tanpa Rokok di Lingkungan Sekolah; Permendikbud No. 82 Tahun 2015 tentang Pencegahan dan Penanggulangan Tindak Kekerasan di Lingkungan Satuan Pendidikan; Permendikbud No. 8 Tahun 2016 tentang Buku yang Digunakan oleh Satuan Pendidikan; Permendikbud No. 18 Tahun 2016 tentang Pengenalan Lingkungan Sekolah Bagi Siswa Baru; Permendikbud No 023 Tahun 2017 tentang Hari Sekolah; Permendikbud No. 20 tahun 2018 tentang Penguatan Pendidikan Karakter pada Satuan Pendidikan Formal; dan Permendikbud No. 18 Tahun 2018 Tentang Penyediaan Layanan Pendidikan Anak Usia Dini.

\section{PEMBAHASAN}

\section{A. Fenomena Child abuse}

Kasus kekerasan atau berbagai perlakuan salah terhadap anak (child abuse) sangat dekat dengan kehidupan anak, seperti kekerasan fisik, seksual verbal, psikis dan cyber bullying. Pengalaman anak- anak berhadapan dengan kekerasan sangat beraneka ragam baik 
dari segi bentuk-bentuk kekerasan yang dialami, pelaku kekerasan, tempat kejadian, dan sebab-sebab terjadinya kekerasan. Kekerasan sering dilakukan bersamaan dengan salah satu bentuk tindak pidana, seperti dengan kekerasan atau ancaman kekerasan atau alat apa yang dipakai, masing-masing tergantung pada kasus yang timbul.

Data kekerasan terhadap anak yang dihimpun oleh Komisi Perlindungan Anak Indonesia (KPAI) terdapat 26.954 laporan yang masuk sepanjang September 2011 sampai dengan September 2017. ${ }^{26}$ Tren pengaduan kasus anak ke KPAI terus meningkat sejak tahun 2015. Menurut data KPAI, jumlah pengaduan kasus anak pada 2015 tercatat 4.309 kasus. Pada tahun 2016 naik menjadi 4.622 kasus. Kemudian pada tahun 2017 turun menjadi 4.579. Namun memasuki tahun 2018 mengalami peningkatan dari tahun-tahun sebelumnya. Berdasarkan data KPAI mencatat kasus pelanggaran hak anak tahun 2018 mencapai 4.885 kasus. $^{27}$

Jumlah kasus anak berhadapan dengan hukum (ABH) pada tahun 2018 masih menduduki urutan pertama, yaitu mencapai 1.434 kasus, disusul kasus terkait keluarga dan pengasuhan alternatif mencapai 857 kasus. Selanjutnya, pornografi dan siber mencapai 679 kasus, pendidikan berjumlah 451 kasus, kesehatan dan Narkotika, Psikotropika, dan Zat Adiktif (Napza) mencapai 364 kasus, trafficking dan eksploitasi anak mencapai 329 kasus. Ia menyebutkan, kasus $\mathrm{ABH}$ didominasi kasus kekerasan seksual. Laki-laki mendominasi sebagai pelaku dibandingkan anak perempuan. Sepanjang tahun 2018, pelaku laki-laki berjumlah 103, sedangkan pelaku berjenis kelamin perempuan, berjumlah 58 anak. ${ }^{28}$

Maraknya terjadi child abuse memperlihatkan seakan tidak ada lagi lingkungan yang benar-benar aman bagi anak, bahkan di lingkungan privat. Lebih separuh kekerasan pada anak melibatkan orang-orang terdekatnya yang seharusnya melindungi. Wajar bila ada anggapan telah terjadi situasi ke-darurat-an perlindungan anak di Indonesia. Karena berbagai kasus terjadi diluar nalar kemanusiaan. Mulai dari lingkungan dalam rumah, lingkungan bermain, hingga lingkungan sekolah tidak lepas dari ancaman terhadap secure (rasa aman) anak.

\section{B. Lingkungan (tidak) bebas dari Napza}

\footnotetext{
${ }^{26}$ Data dari website resmi KPAI, "KPAI Nilai Sekolah Berperan Penting untuk Hentikan Bullying," 4 Oktober 2017. http://www.kpai.go.id/berita/kpai-nilai-sekolah-berperan-penting-untuk-hentikan-bullying/.

${ }^{27}$ Dimuat dalam situs resmi Komisi Perlindungan Anak Indonesia, http://www.kpai.go.id/berita/kpai-4-885kasus-pelanggaran-hak-anak-terbanyak-abh. Diakses tanggal 18 Januari 2019.

${ }^{28}$ Ibid.
} 
Khusus terkait kesehatan dan Napza (Narkotika, rokok, minuman keras dan sebagainya), berdasarkan data KPAI (Komisi Perlindungan Anak Indonesia) sepanjang tahun 2018 terdapat 364 kasus. Kasus ini mulai dari akses pelayanan kesehatan, korban malpraktek, korban keracunan dan penyakit menular, hingga pengguna dan pengedar Napza. $^{29}$

Kondisi yang memperihatinkan adalah keterlibatan anak dalam peredaran Narkoba sebagaimana data temuan KPAI. Komisioner Bidang Kesehatan KPAI, Sitti Hikmawatty, dalam konferensi pers nya di Kantor KPAI pada tanggal 6 Maret 2018, mengungkapkan bahwa adanya peningkatan keterlibatan anak dalam peredaran gelap narkoba. Anak semakin sering ditemukan menjadi kurir hingga korban penyalahgunaan barang haram itu. Terdapat modus pengedar Narkoba yang mengincar anak-anak berprestasi dengan tujuan merusak agar tidak tercapainya bonus demografi pada $2025 .{ }^{30}$ Berdasarkan data KPAI, dari total 87 juta anak yang berusia maksimal 18 tahun tercatat 5,9 juta yang terpapar sebagai pecandu narkoba, 27 persen di antaranya adalah anak-anak yakni 1,6 juta anak sebagai pengedar. ${ }^{31}$

Fenomena mencengangkan seperti beredarnya video yang memperlihatkan beberapa anak SD dengan lihai bergiliran menghisap vape (rokok elektrik) di belakang sekolah, trenggalek, jawa timur, di bulan agustus 2017. Kemudian, pemberitaan tentang jajanan permen dan pil yang mengandung zat Narkoba dalam beberapa tahun terakhir. Jajanan permen yang diduga mengandung narkoba ditemukan beredar di beberapa daerah. Seperti yang pernah terjadi pada tahun 2017, seorang pelajar menjadi korban dengan diberi obat berbahaya berbentuk permen di depan sekolahnya di kota Malang.

Di tahun yang sama pula, kita dihebohkan dengan beredarnya Pil Paracetamol, Caffeine, Carisoprodol (PCC) di kalangan anak-anak di Kendari. ${ }^{32} 53$ anak SD dan SMP di Kendari kejang-kejang akibat Pil PCC, bahkan satu orang meninggal dunia. Berdasarkan penelusuran pihak aparat kepolisian bahwa mata rantai peredaran pil PCC bahan-bahan

\footnotetext{
29 Ibid.

30 Dikemukakan oleh Komisioner Komisi Perlindungan Anak Indonesia (KPAI) Bidang Kesehatan, Siti Hikmawati dalam konferensi pers di Jakarta, Selasa, 6 Maret 2018. Dapat diakses di https://www.republika.co.id/berita/nasional/umum/18/03/06/p55utk428-kpai-sindikat-narkoba-mengincaranak-berprestasi.

31 Dikemukakan oleh Komisioner Komisi Perlindungan Anak Indonesia (KPAI) Bidang Kesehatan, Siti Hikmawati dalam konferensi pers di Jakarta, Selasa, 6 Maret 2018. Dapat diakses di https://news.okezone.com/read/2018/03/06/337/1868702/5-9-juta-anak-indonesia-jadi-pecandu-narkoba.

32 Peredaran obat pil PCC sebenarnya telah dilarang sejak 2013. Pil PCC merupakan obat keras yang masuk dalam golongan G. Kebanyakan obat ini juga difungsikan untuk orang yang memiliki penyakit jantung. Masyarakat harus mendapatkan resep dokter untuk mengonsumsinya.
} 
pembuatannya yang digudangkan di Cimahi, Jawa Barat diimpor dari China. ${ }^{33}$ Kemudian proses pembuatan (produksi) pil PCC berada di Purwokerto, Jawa Tengah. Pabrik ini mampu menghasilkan ratusan ribu dalam semalam. ${ }^{34}$ Selanjutnya untuk pengemasan dan distribusi dilakukan di Surabaya, Jawa Timur. Dari Surabaya kemudian didistribusikan ke wilayah Indonesia Timur, seperti Sulawesi, Maluku dan Papua. ${ }^{35}$

Apa yang telah terjadi di Kendari yang menyebabkan korban anak-anak akibat mengkomsumsi pil PCC membuka mata kita semua bahwa betapa tidak awasnya semua pihak sehingga jajanan yang berbahaya dapat dijangkau oleh anak-anak. Peredaran Narkoba serta jajanan yang berbahaya bagi anak-anak di atas menambah daftar ancaman yang senantiasa menghampiri setiap anak.

Anak-anak tidak lagi bebas melakukan jajan, baik di lingkungan sekitar rumah, ruang publik maupun di lingkungan pendidikan (sekolah). Padahal, anak-anak tidaklah mungkin dalam pengawasan orang tua sepanjang hari. Bukanlah solusi ketika anak cukup dalam rumah saja karena lingkungan di luar rumah tidak aman. Walaupun dengan beragam fasilitas dan permainan dalam rumah didapatkan, tetapi tanpa aktivitas fisik atau tanpa berinteraksi dan berkreasi dengan teman sebaya mereka di luar rumah, maka langkah itu bukanlah hal bijak untuk kesehatan dan pertumbuhan anak. Banyak penelitian telah membuktikan pentingnya lingkungan yang aman dan sehat bagi pertumbuhan anak disamping faktor genetik.

\section{Child Abuse di Lingkungan Pendidikan}

Sekolah merupakan lingkungan pendidikan yang telah menjadi bagian dari kehidupan anak-anak. Selain hadir secara fisik, anak-anak mengikuti berbagai kegiatan yang telah dirancang dan diprogram sedemikian rupa. Sekolah memiliki peran yang sangat berarti bagi perkembangan anak diluar lingkungan keluarga. Ironinya, peristiwa kekerasan dan pelanggaran hak anak lainnya (child abuse) terjadi di lingkungan pendidikan. KPAI

\footnotetext{
33 Penggerebekan yang dilakukan pihak kepolisian pada tanggal 18 September 2017 di Cimahi Selatan menemukan gudang berisi empat ton bahan baku pil PCC.

https://nasional.kompas.com/read/2017/09/22/16074841/polisi-bongkar-produsen-pil-pcc-ini-kronologinya

${ }^{34}$ Penggerebekan yang dilakukan pihak kepolisian pada tanggal 19 september 2017 terhadap pabrik PCC yang berkedok toko isi ulang air minum di Jalan Raya Baturaden No 182 dan 184, RT 2 RW 1 Kelurahan Pabuaran Purwokerto Utara, Banyumas, ditemukan barang bukti 2 drum pil PCC, 1 drum pil Zenit, 9 drum bahan baku untuk membuat pil PCC, 1 unit mesin produksi dan 2 buah oven pencetak pil.

${ }^{35}$ Penggerebekan yang dilakukan pihak kepolisian terhadap gudang pil PCC di Perumahan Wisma Permai Timur 1 Surabaya pada tanggal 19 september 2017 menemukan barang bukti antara lain 32 karung berisi 1.280.000 butir obat jenis Zenith, dan 10 karung berisi plastik kemasan Zenith sebanyak 120.000 lembar. Ditemukan pula tujuh karton berisi 35.000 butir obat carnophen, 36 roll bertuliskan CPC, sebuah mesin press plastik dan 100 botol berisi 100.000 butir dextrometeophan.
} 
mencatat sejumlah pelanggaran hak anak di bidang pendidikan tahun 2018. Pelanggaran tersebut didominasi oleh kekerasan di lingkungan sekolah. Terdapat 445 kasus bidang pendidikan yang ditangani sepanjang 2018, sebanyak 228 kasus atau 51,20 persen di antaranya merupakan kasus kekerasan baik fisik, seksual, dan verbal. ${ }^{36}$

Tingginya kasus kekerasan anak (child abuse) di lingkungan sekolah baik yang dilakukan guru pada siswa, siswa terhadap guru, maupun siswa terhadap siswa lainnya, juga diperlihatkan data berdasarkan Ikhtisar Eksekutif Strategi Nasional Penghapusan Kekerasan Terhadap Anak 2016-2020 oleh Kemen-PPPA. Adapun datanya adalah sebagai berikut:

\begin{tabular}{|l|r|}
\hline \multicolumn{1}{|c|}{ Kasus Kekerasan di Sekolah } & Persentase \\
\hline Siswa pernah mengalami kekerasan di sekolah & $84 \%$ \\
\hline $\begin{array}{l}\text { Siswa laki-laki menyebutkan bahwa guru atau petugas sekolah } \\
\text { merupakan pelaku kekerasan }\end{array}$ & $45 \%$ \\
\hline $\begin{array}{l}\text { Siswa usia 13-15 tahun melaporkan pernah mengalami kekerasan fisik } \\
\text { oleh teman sebaya }\end{array}$ & $40 \%$ \\
\hline Siswa mengakui pernah melakukan kekerasan di sekolah & $75 \%$ \\
\hline $\begin{array}{l}\text { Siswa perempuan menyebutkan bahwa guru atau petugas sekolah } \\
\text { merupakan pelaku kekerasan }\end{array}$ & $22 \%$ \\
\hline Anak melaporkan mengalami perundungan (bullying) di sekolah & $50 \%$ \\
\hline
\end{tabular}

Sumber : Kemen-PPPA, Ikhtisar Eksekutif Strategi Nasional Penghapusan Kekerasan Terhadap Anak 2016-2020.

Arliman S, Laurensius (2017) mencatat child abuse yang terjadi di lingkungan sekolah, seperti: 1) Guru memukul anak muridnya; 2) Guru mencabuli anak muridnya; 3) Guru menghardik anak muridnya; 4) Guru mengeluarkan kata-kata yang tidak pantas kepada muridnya; 5) Guru memberikan pengajaran yang tidak sesuai dengan semestinya; 6) Guru tidak memberikan pengajaran dengan berbagai alasan; 7) Guru melakukan pembiaran kepada tingkah laku anak muridnya, dan lain sebagainya dalam konteks merugikan anak. Selain dari guru, lingkungan sekolah juga melakukan tindakan yang melanggar perlindungan anak di sekolah, misalkan saja: 1) Teman-teman memukuli salah seorang temannya; 2) Siswa melakukan tindakan bullying; 3) Siswa melakukan kekerasan seksual

\footnotetext{
${ }^{36}$ Dikemukakan oleh Komisioner KPAI, Retno Listyarti di kantor KPAI, Jakarta, Kamis, 27 Desember 2018. Lihat https://nasional.tempo.co/read/1159391/kpai-pelanggaran-hak-anak-di-2018-didominasi-tindakkekerasan
} 
kepada sesama siswa; 4) Masyarakat sekolah (sekuriti, penjaga sekolah, pembersih sekolah, dan lainnya) melakukan hal yang tidak senonoh kepada anak. ${ }^{37}$

Banyak terjadi child abuse yang melibatkan guru sebagai pelaku, dimana guru sebagai orang tua anak di sekolah melakukan tindakan yang tidak terpuji. Sejatinya, lingkungan pendidikan merupakan wadah bagi anak untuk menimbah ilmu dan nilai-nilai luhur agar tumbuh dan berkembang menjadi lebih baik. Publik terus menyaksikan kejadian kekerasan anak, diliput oleh berbagai media TV, lewat media cetak maupun media online. Ketua KPAI, Susanto (2016) mengemukakan bahwa kekerasan terhadap anak di sekolah merupakan persoalan bangsa yang perlu segera dihentikan dan diputus mata rantainya karena terkait langsung dengan pemenuhan hak anak untuk dilindungi oleh negara serta menentukan nasib bangsa di masa mendatang. Pada saat yang sama kekerasan di sekolah menjadi masalah yang membutuhkan peran negara untuk menyikapinya secara serius dan sistemik. ${ }^{38}$

Fenomena lain dari praktek child abuse yang masih terjadi di sekolah adalah pemberian hukuman fisik dan hukuman merendahkan. Bagi Indonesia, hukuman fisik (kekerasan) dan hukuman merendahkan hampir tak dapat dilepaskan dari potret sosial budaya masyarakat, bahkan terkadang masih dilegalisasi dan masih diterima oleh mayarakat tertentu. Pola-pola tradisional dalam memberikan hukuman sarat dengan hukuman fisik, seperti hukuman yang melibatkan pemukulan dengan tangan atau objek lain seperti tongkat, penggaris, ikat pinggang, cambuk, sepatu; menendang, melempar, mencubit, menjambak, menyuruh siswa untuk berdiri pada posisi yang tidak menyenangkan, atau menyuruh siswa untuk melakukan kegiatan fisik yang berlebihan, menakuti siswa. Selain hukuman fisik, terdapat pula hukuman yang merendahkan seperti menghina dan berkata kasar.

Hukuman fisik dan hukuman merendahkan terbukti tidak efektif untuk menegakkan disiplin. Beberapa fakta penerapan hukuman fisik menyebabkan kesehatan mental terganggu, termasuk diantaranya depresi, tidak bahagia, cemas, perasaan hampa dalam diri siswa. Selain itu berdasarkan bukti-bukti medis dan psikologis, hukuman fisik dan hukuman yang merendahkan menyebabkan anak beresiko mengalami fisik yang terganggu, kesehatan mental yang terganggu, hubungan interpersonal yang tidak sehat, internalisasi nilai-nilai moral yang lemah, prilaku anti sosial, kemampuan beradaptasi yang terganggu.

\footnotetext{
${ }^{37}$ Laurensius Arliman S, "Dinamika dan Solusi Perlindungan Anak di Sekolah," Jurnal Selat Vol. 4 No. 2 , (Mei 2017) : 226

38 Susanto, "Quo Vadis Perlindungan Anak di Sekolah: Antara Norma dan Realita," Rabu 20 Januari 2016, lihat dalam https://news.detik.com/kolom/3122977/quo-vadis-perlindungan-anak-di-sekolah-antara-normadan-realita.
} 
Penelitian yang dilakukan Dr Ruth Payne di Inggris yang diterbitkan pada tahun 2015 lalu mengamati reaksi siswa sekolah menengah kelas 7 (berusia 11-12 tahun) dan kelas 11 (berusia 15-16 tahun) terhadap hukuman. Payne menyimpulkan bahwa:

"The findings show a complex range of pupil responses to different behaviour management strategies, as well as highlighting changes in pupil responses across the age groups. Some sanctions for classroom behaviour are also found to lead pupils to stay quiet, potentially affecting their ability to engage in all learning activities. Sanctions such as asking pupils to miss break, or giving detentions, are seen to be counter-productive in encouraging pupils to work hard in class." 39

Payne menemukan sanksi berupa pengebirian jam main terbukti gagal membuat anak berperilaku lebih baik. Begitupula dengan menegur siswa di depan kelas atau menghukum seluruh siswa karena kesalahan segelintir dari mereka juga tak efektif. Hukuman tersebut malah menciptakan kebencian dan merusak hubungan antara siswa dengan guru.

Sebagai salah satu negara yang sudah meratifikasi Konvensi Hak Anak, ${ }^{40}$ maka sudah selayaknya anak-anak Indonesia mendapatkan rasa aman dan nyaman dalam peningkatan kualitasnya. Kekerasan terhadap anak (child abuse) sudah seharusnya tidak terjadi lagi di lingkungan pendidikan.

\section{Banyak Regulasi Saja Tidak Cukup}

Berdasarkan penelitian yang dilakukan oleh Ahmad Sofian, terdapat 22 undangundang yang memberikan perlindungan terhadap anak-anak dari praktek kekerasan, eksploitasi, penelantaran dan perlakuan salah. Ada juga yang mengatur masalah perlindungan anak secara tidak langsung, bahkan sebagian adalah ratifikasi konvensi (opsional protokol) internasional, semuanya memiliki relasi atau keterkaitan dengan perlindungan anak di Indonesia. ${ }^{41}$

Menurut Ahmad Sofian, Undang-Undang Perlindungan Anak menjadi catatan khusus, karena undang-undang ini telah dua kali mengalami revisi, dan revisi yang dilakukan tidak didasarkan pada semangat untuk melakukan harmonisasi dengan standard internasional yang diratifikasi tetapi lebih didasarkan pada respon atas persoalan-persoalan anak yang mengemuka atau muncul di masyarakat. Dengan kata lain revisi yang dilakukan

\footnotetext{
${ }^{39}$ Ruth Payne, "Using rewards and sanctions in the classroom: pupils' perceptions of their own responses to current behaviour management strategies," Journal Educational Review, Volume 67 (2015): 483-504

${ }^{40}$ Ratifikasi Konvensi Hak Anak (KHA) sudah dilakukan Pemerintah Indonesia sejak tahun 1990 melalui Keputusan Presiden Nomor 36 Tahun 1990.

${ }^{41}$ Ahmad Sofian, Januari 2017. Legal Review Perlindungan Anak Di Indonesia. Dimuat di http://businesslaw.binus.ac.id/2017/01/30/legal-review-perlindungan-anak-di-indonesia/ Diakses tanggal 20 Oktober 2018.
} 
masih bersifat parsial dan kasuistis. Oleh sebab itu, revisi yang sudah dilakukan tidak menjawab pengentasan persoalan anak secara menyeluruh. ${ }^{42}$ Faktanya, berbagai regulasi yang ada belum cukup dalam memberikan perlindungan terhadap anak. Kekerasan terhadap anak (child abuse) masih tinggi dan mengalami peningkatan setahun terakhir di Indonesia. ${ }^{43}$

Begitupula hasil penelitian yang dilakukan Rini Fitriani (2016) bahwa pengaturan tentang hak-hak anak telah terakomodir dalam beberapa perundang-undangan Negara Republik Indonesia, tetapi implementasinya masih jauh dari harapan karena masih banyaknya kasus-kasus (child abuse) yang terjadi, kekerasan, ketidakadilan, penelantaran, diskriminasi, eksploitasi, maupun perbuatan negatif lain.

Selain itu, persoalan lain yang muncul adalah kebingungan terhadap regulasi memungkinkan dialami oleh korban kekerasan anak (Child abuse) lantaran skema regulasi di Indonesia yang terpecah-pecah. Misalkan ada di Undang-Undang Kekerasan dalam Rumah Tangga (KDRT), ada di Undang-Undang Trafficking, ada prihal cyber bullying di Undang-Undang ITE, ada di undang-undang perlindungan anak, ada Undang-Undang Perlindungan Saksi Korban. Sehingga korban kekerasan anak (Child abuse) tidak sepenuhnya tahu kemana akan mengadu. Beragam regulasi tersebut harus mendapatkan titik terang bagi masyarakat, jangan sampai dipahami hanya oleh para pengambil kebijakan dan lembaga-lembaga perlindungan anak saja. Peran sosialisasi dari KPAI mengenai perihal regulasi ini masih perlu ditingkatkan.

Selain aspek regulasi dan kelembagaan, beragam program yang dilakukan Lembaga Pemerintah (Kementerian Perlindungan Anak) dan Komisi Perlindungan Anak Indonesia (KPAI) sebagai representasi kehadiran negara juga belum signifikan nyata dirasakan dalam meningkatkan rasa aman (secure) terhadap anak dari berbagai ancaman baik di ruang private, di lingkungan sekolah, maupun lingkungan publik. Kasus-kasus terhadap hak anak masih terus menjadi pemberitaan yang memenuhi media cetak maupun online.

\section{E. Menciptakan Lingkungan Interaksi Anak Yang Aman dan Sehat}

Mencermati kondisi lingkungan anak dengan berbagai permasalahannya saat ini, maka tidak ada lagi jaminan keamanan maupun kesehatan anak terhadap lingkungan sekitarnya, baik privat maupun publik. Rentannya lingkungan baik dari aspek rasa aman maupun bagi kesehatan anak menjadi ancaman serius bagi kelangsungan generasi masa

\footnotetext{
42 Ibid.

${ }^{43}$ Lihat Data KPAI yang disajikan dalam tulisan ini.
} 
depan bangsa. Padahal, lingkungan yang ideal bagi anak minimal mensyaratkan 2 hal, yaitu aspek keamanan anak (seperti rasa aman secara fisik dan nyaman secara psikis) dan lingkungan yang sehat bagi anak (seperti jajanan yang sehat, terbebas dari Napza).

Oleh karena itu, menciptakan lingkungan yang aman dan sehat bagi pertumbuhan dan perkembangan anak memerlukan andil semua pihak untuk menjaga, memberikan teladan, dan menjauhkan dari hal-hal yang selayaknya berbahaya bagi anak, sehingga anakanak dapat tumbuh dan berkembang menjadi generasi yang lebih baik, generasi yang diharapkan bangsa dan negara. Masyarakat harus betul-betul peduli dan mengawasi lingkungan yang memberi dampak buruk terhadap anak, karena lingkungan bagi anak-anak merupakan interaksinya dengan sesama anak atau dengan orang dewasa, juga sebagai sarana memusatkan perhatian dalam melakukan aktivitas.

Begitupula keamanan lingkungan. Salah satu fungsi lingkungan bagi anak sebagai sarana bermain. Pentingnya lingkungan bermain karena berkaitan erat dengan pertumbuhan anak, ${ }^{44}$ secara langsung mempengaruhi seluruh wilayah dan aspek perkembangan anak. Di saat bermain, anak-anak akan menyerap segala sesuatu yang terjadi di lingkungan sekitarnya. Adanya ruang dan waktu bermain bagi anak menghasilkan interaksinya dengan orang lain, berimajinasi, bereksplorasi, dan mencipta sesuatu.

Kegiatan bermain mempengaruhi perkembangan keenam aspek perkembangan anak, yakni aspek kesadaran diri (personal awareness), emosional, sosialisasi, komunikasi, kognisi, dan keterampilan motorik. ${ }^{45}$ Keenam aspek tersebut dapat diuraikan, sebagai berikut:

Pertama, Aspek kesadaran personal. Bermain melatih anak untuk tumbuh secara mandiri dan memiliki kontrol atas lingkungannya. Melalui bermain anak dapat menemukan hal baru, bereksplorasi, dan mempraktikan kehidupan sehari-hari sebagai langkah untuk membangun berbagai keterampilan agar membuat anak merasa kompeten.

Kedua, Aspek pengembangan emosi. Melalui bermain anak dapat belajar menerima, berekspresi dan mengatasi masalah dengan cara yang positif. Bermain juga memberikan kesempatan anak untuk mengenal diri mereka dan untuk mengembangkan perilaku yang memuaskan dalam hidup.

\footnotetext{
${ }^{44}$ Catherine Garvey, "The developing child series. Play (Enlarged ed.)" Paperback, 1 November 1990 (Cambridge, MA, US: Harvard University Press, 1990)

${ }^{45}$ Catron dan Allen, Early Childhood Curriculum: A Creative Play Model, 4th Edition, (New York: Merrill, Prentice Hall, 2007), 23-26
} 
Ketiga, Aspek membangun sosialisasi. Bermain memberikan jalan bagi perkembangan sosial anak ketika berhadapan dengan anak lain. Mereka bisa bersosialisasi melalui bermain, dan juga memperluas empati terhadap orang lain dan mengurangi sikap egosentrisme. Melalui bermain juga anak dapat belajar sikap prososial seperti kerja sama, berbagi dan saling membantu.

Keempat, Aspek pengembangan komunikasi. Bermain merupakan alat yang paling kuat untuk mengembangkan kemampuan berbahasa anak, dan bisa memperluas kosa kata anak dengan cara berkomunikasi dengan anak lain. Selain itu, anak dapat mengekspresikan kemampuan berbahasa nya dengan cara berinteraksi dengan anak lain atau dengan orang dewasa secara spontan.

Kelima, Aspek kognitif/intelektual. Kemampuan berpikir ini dapat direfleksikan oleh anak melalui kemampuannya untuk membayangkan benda-benda yang berada di sekitarnya secara mental. Kemampuan berpikir secara intuitif dan berpusat pada cara pandang anak itu sendiri atau egosentris.

Keenam, Aspek perkembangan motorik. Aspek perkembangan motorik merupakan salah satu aspek perkembangan yang dapat mengintegrasikan perkembangan aspek yang lain. Anak juga mendapatkan kesempatan yang luas untuk bergerak, pengalaman belajar untuk menemukan, aktivitas sensori motor yang meliputi penggunaan otot-otot besar dan kecil memungkinkan anak untuk memenuhi perkembangan perseptual motorik.

Dengan demikian, menciptakan lingkungan yang aman dan sehat sangat penting bagi proses pertumbuhan anak, baik itu dalam rumah, lingkungan tempat tinggal, lingkungan pendidikan, maupun lingkungan dimana anak berinteraksi.

\section{F. Lingkungan Pendidikan yang Ideal}

Pentingnya menciptakan lingkungan pendidikan (sekolah) yang ideal agar siswa dapat mencapai prestasi yang terbaik dan guru dapat menampilkan kinerja yang terbaik. Oleh karena itu, hendaknya lingkungan sekolah harus mampu menjamin 3 (tiga) yaitu aspek aman, nyaman, dan disiplin. Keamanan, kenyamanan dan kedisiplinan suatu sekolah ditentukan oleh nilai-nilai dan sikap warga sekolah, termasuk kepala sekolah, guru, siswa, orang tua, komite sekolah.

Aspek keamanan dapat terbangun dengan memperhatikan kondusifitas lingkungan fisik maupun kebijakan di lingkungan sekolah. Faktor fisik seperti bangunan fisik sekolah, tata letak serta halaman bermain. Selain itu, kebijakan dan prosedur yang ada dikaji ulang 
untuk melaksanakan kegiatan sehari-hari dan menyelesaikan masalah yang mungkin timbul. Misalnya, penggunaan teknologi untuk mencegah orang masuk penyusup masuk dari luar seperti alarm, pagar, teralis, CCTV, harus dipertimbangkan. Begitupula kebijakan mengenai antar jemput anak. Sebaiknya disepakati bersama oleh pihak sekolah dengan orang tua wali anak/siswa. Misalnya, sistem $e$-card atau kartu tanda pengenal penjemput anak/siswa yang dikenali oleh pihak sekolah. Sistem ini dapat mencegah terjadinya hal-hal yang tidak diinginkan seperti kasus penculikan anak, dan lain-lain.

Adapun aspek kenyamanan yaitu menyangkut iklim sekolah secara sosial dan emosional. Adapun faktor-faktor yang mempengaruhi kenyamanan atau iklim sekolah antara lain, hubungan atau keterikatan antar warga sekolah, interaksi antar warga sekolah, rasa saling mempercayai dan saling menghargai antar warga sekolah. Salah satu yang mengganggu kenyamanan yang perlu penanganan di lingkungan sekolah adalah kekerasan terhadap siswa yang lebih lemah (bullying). Bullying adalah suatu situasi dimana seorang siswa atau lebih secara terus menerus melakukan tindakan yang menyebabkan siswa lain menderita.

Kekerasan terhadap siswa yang lebih lemah ini dapat berbentuk secara fisik (memukul, menendang, mengambil milik orang lain), secara verbal (mengolok-olok nama siswa lain, menghina, mengucapkan kata-kata yang menyinggung), dan secara tidak langsung (mengucilkan, menjadikan siswa tertentu sebagai target humor yang menyakitkan, mengirim pesan pendek atau surat yang keji, menyebarkan berita bohong). Agar kekerasan terhadap anak (siswa) yang lebih lemah ini tidak terjadi maka perlu dibuat aturan sekolah untuk memberikan perlindungan, baik sebagai langkah pencegahan (preventif) maupun strategi penanganan terjadinya bullying. Sekolah harus mempunyai catatan yang akurat tentang kejadian kekerasan yang terjadi di sekolah dan bagaimana cara menanganinya untuk keperluan monitoring dan untuk melindungi sekolah dari tuntutan hukum. Selain itu, agar dapat melakukan strategi pencegahan dini, sekolah dapat membuat data potensial bullying yang dapat terjadi di lingkungan sekolahnya dan langkah penanganannya.

Secara menyeluruh, warga sekolah mempunyai komitmen yang mendalam dalam menciptakan dan menjaga sekolah terbebas dari praktek kekerasan, bullying dan semacamnya yang berdampak psikis terhadap anak/siswa. Kenyamanan dapat terbangun bila warga sekolahnya bebas dari rasa takut, kondusif untuk belajar dan hubungan antar warga sekolahnya positif. Dengan terwujudnya faktor-faktor kenyamanan lingkungan sekolah maka sekolah menjadi wadah pendidikan sebagaimana yang diharapkan dan terhindar dari praktek-praktek yang digolongkan sebagai child abuse. 
Selanjutnya, aspek kedisiplinan. Salah satu yang digunakan dalam memotivasi belajar siswa maupun penegakan disiplin adalah dengan pemberian hukuman. Pada dasarnya hukuman merupakan tindakan yang diberikan oleh pendidik terhadap anak didik yang telah melakukan kesalahan, dengan tujuan agar anak didik tidak akan mengulanginya lagi dan akan memperbaiki kesalahan yang telah ia perbuat. Pemberian hukuman harus dapat mendidik dan menyadarkan peserta didik. Meskipun demikian, hukuman tidak identik dengan hukuman fisik (kekerasan) atau hukuman merendahkan. Pemberian hukuman harus dipisahkan pemberian hukuman dan pemberian kekerasan meskipun sama-sama bertujuan untuk menghentikan perilaku-perilaku tertentu. Hukuman lebih dilandasi komitmen moral dengan tujuan mendidik. Sedangkan hukuman fisik (kekerasan) dilakukan tidak lagi mendidik karena melibatkan emosi (amarah atau kekesalan) dan dampaknya berbahaya bagi fisik maupun psikis anak.

Hukuman fisik merupakan pelanggaran hak asasi anak dalam hal integritas fisik dan kehormatannya sebagai manusia seperti dicanangkan dalam Konvensi PBB tentang hak-hak anak. Lebih dari 20 negara di dunia telah menerbitkan undang-undang atau peraturan yang melarang hukuman fisik kepada siswa di sekolah. Gerakan mendunia untuk mengubah budaya menghukum secara fisik merupakan momentum yang baik untuk Indonesia melakukan transformasi dan akselerasi pendidikan tanpa kekerasan, sehingga dapat mencegah dan menekan terjadinya child abuse di lingkungan sekolah.

Tidak hanya guru, termasuk pula orang tua, bagaimana memberikan hukuman yang tepat kepada siswa/anak, serta bagaimana menumbuhkan kedisiplinan tanpa pemberian hukuman. Dengan demikian, kedisiplinan yang diharapkan adalah langkah-langkah atau upaya yang perlu guru, kepala sekolah orang tua dan siswa ikuti untuk mengembangkan keberhasilan prilaku siswa secara akademik maupun sosial.

\section{G. Kebijakan dan Langkah bersama dalam Perlindungan Anak}

Anak-anak membutuhkan lingkungan aman dan sehat untuk aktivitas fisik maupun psikis, berinteraksi, bermain, dan berkreasi sehingga mereka dapat tumbuh dengan baik menjadi generasi masa depan yang diharapkan. Berbagai kasus yang masih terus terjadinya terhadap keamanan lingkungan untuk pertumbuhan dan perkembangan anak, baik di lingkungan rumah tangga, sekolah maupun di lingkungan publik, mengindikasikan bahwa memperbanyak regulasi saja tidak cukup. Lebih dari itu, memerlukan kebijakan dan langkah 
bersama Pemerintah dan lembaga pendidikan untuk meningkatkan upaya dalam memberikan perlindungan terhadap anak, antara lain:

Pertama, Komisi Perlindungan Anak Indonesia (KPAI) meningkatkan sosialisasi perlindungan anak di lingkungan pendidikan maupun di masyarakat. Sosialisasi ini berisi semua yang terkait produk hukum dan kebijakan pemerintah dalam perlindungan hak anak. KPAI bukan lembaga yang hanya bertugas menghitung angka-angka kekerasan terhadap anak atau penerima pengaduan, tetapi lebih dari itu merupakan sebuah lembaga Pemerintah yang sesuai namanya mencatut "Perlindungan Anak Indonesia." Oleh karena itu, KPAI harus nyata dirasakan oleh masyarakat dalam upaya-upaya perlindungan anak. Misalnya, KPAI harus proaktif menghadiri pertemuan parenting (forum orang tua siswa) maupun dalam pertemuan guru-guru. Langkah ini sebagai upaya pencegahan timbulnya kasus kekerasan anak dan kasus anak lainnya yang dapat terjadi di lingkungan sekolah.

Kedua, Kementerian Pendidikan atau inisiatif sekolah harus terus mengembangkan kemampuan guru baik dengan pengetahuan dan wawasan untuk mengembangkan kreativitas mereka terutama dalam mengembangkan metode pengajaran yang menarik tanpa keluar dari prinsip dan nilai-nilai pendidikan. Sekolah dituntut untuk meninggalkan pola-pola lama dalam mewarisi tradisi pemberian hukuman fisik (kekerasan) dan hukuman merendahkan. Pendisiplinan bertransformasi ke arah keteladanan dan raihan prestasi dari ilmu pengetahuan yang didapatkan. Pentingnya sekolah mewujudkan pendidikan tanpa kekerasan, karena sekolah sebagai tempat menimbah ilmu pengetahuan juga tempat menempa karakter anak sehingga guru-guru harus mampu menjadi teladan baik perkataan maupun perbuatan di sekolahnya.

Ketiga, Kementerian Pendidikan harus mewajibkan pihak Sekolah untuk bisa memberikan pendidikan psikologi dan pemberian konseling pada para guru untuk memahami perkembangan dan dinamika kejiwaan anak baik secara umum seiring perkembangan masyarakat kekinian maupun hal khusus yang diperlukan bagi seorang guru dalam mendidik. Pendekatan psikologi bagi guru diharapkan dapat menemukan cara yang lebih efektif dan sehat untuk menghadapi anak didik. Adapun pemberian konseling kepada guru juga dibutuhkan, bukan hanya siswa. Kondisi guru bisa dalam satu waktu berada pada situasi sulit yang membutuhkan dukungan atau bimbingan dalam menghadapi masalahnya.

Keempat, Pemerintah memperioritaskan bantuan sekolah untuk fasilitas pengawasan (Misalnya dengan tenaga pengawas atau pemasangan CCTV) di lingkungan sekolah. Semakin banyak pemasangan CCTV di area publik maupun di lingkungan sekolah, dapat 
mendukung tindakan security (keamanan), preventif (pencegahan), bahkan dapat menjadi bukti atau bahan penyidikan bagi aparat keamanan bila terjadi kasus di lingkungan tersebut.

Kelima, Badan Pengawas Obat dan Makanan (BPOM) bekerjasama dengan Pihak sekolah bertanggung jawab dan memastikan jajanan dan peredaran makanan di lingkungan sekolah aman dan sehat. Jajanan merupakan hal yang tak pernah lepas dari anak sekolah. Jajanan yang bergizi dan bermutu untuk dikonsumsi bagi anak anak adalah faktor utama yang harus diperhatikan oleh pihak sekolah. BPOM dapat secara kontinyu meninjau jajanan makanan di lingkungan sekitar sekolah. Hal ini guna memberikan rasa aman anak-anak terhadap jajanan di sekolah, seperti kantin sekolah, catering sekolah hingga para penjual jajanan yang berada di lingkungan sekolah.

Keenam, perlunya sinergi Kementerian, Lembaga Pemerintah dan Lembaga masyarakat terkait perlindungan anak. Walaupun di negara ini telah ada kementerian Pemberdayaan Perempuan dan Perlindungan Anak (Kemen PPPA), Kementerian Sosial (rehabilitasi, jaminan, pemberdayaan, perlindungan sosial termasuk anak), Kementerian Pendidikan dan Kebudayaan (bidang pendidikan anak usia dini, pendidikan dasar, pendidikan menengah dan pendidikan masyarakat) dan lembaga pemerintah (KPAI) serta lembaga masyarakat (seperti Komnas PA) yang khusus terkait perlindungan anak, namun tanpa kebijakan dan implementasi program yang nyata dan sinergis maka kasus-kasus yang mengancam anak tidak dapat ditanggulangi secara efektif.

\section{PENUTUP}

\section{A. Simpulan}

Maraknya berbagai kasus child abuse memperlihatkan seakan tidak ada lagi lingkungan yang benar-benar aman bagi anak. Bahkan lebih dari separuh kekerasan pada anak melibatkan orang-orang terdekatnya yang seharusnya melindungi. Pada saat yang sama kekerasan di sekolah menjadi masalah yang membutuhkan peran negara untuk menyikapinya secara serius dan sistemik.

Keamanan lingkungan merupakan hal yang krusial dalam perlindungan anak. Lingkungan merupakan tempat dimana anak diberikan kesempatan sebaik-baiknya untuk perkembangan secara fisik, seperti mendapatan pengasuhan, pendidikan yang baik, serta jaminan kesehatan, maupun perkembangan psikisnya, seperti memberikan rasa aman dan rasa nyaman, meningkatkan rasa percaya diri, menjauhkan anak dari hal-hal yang berbahaya, seperti pengaruh penggunaan Napza, serta terbebas dari segala pengaruh buruk dari interaksi 
di sekitarnya. Oleh karena itu, dalam memberikan perlindungan terhadap anak di lingkungannya, maka diperlukan, antara lain: 1) menciptakan lingkungan interaksi anak yang aman dan sehat, 2) menciptakan lingkungan pendidikan yang ideal bagi anak, dan 3) adanya kebijakan dan langkah bersama, negara, pemerintah, pemerintah daerah, masyarakat, keluarga, dan orang tua atau wali berkewajiban dan bertanggung jawab terhadap penyelenggaraan perlindungan anak.

\section{B. Saran}

Pemerintah Indonesia harus mampu menjamin pemenuhan hak dan perlindungan anak-anak Indonesia. Kekerasan terhadap anak baik dalam lingkungan rumah tangga, di sekolah maupun di lingkungan publik merupakan persoalan bangsa yang perlu segera dihentikan dan diputus mata rantainya karena terkait langsung dengan pemenuhan hak anak untuk dilindungi oleh negara serta menentukan nasib bangsa di masa mendatang.

Masa depan kualitas bonus demografi yang akan dialami Indonesia pada tahun 20252030 tentunya dipengaruhi oleh generasi hari ini, terutama perlindungan terhadap hak-hak anak. Disadari bahwa perlindungan terhadap anak merupakan kewajiban bagi kita semua mengingat anak merupakan masa depan dan generasi penerus cita-cita bangsa. Namun demikian, negara sebagai organisasi tertinggi dan terkuat juga memiliki andil yang besar dalam melindungi hak-hak anak.

Negara harus memastikan dan wajib memenuhi hak setiap anak. Tidak cukup dengan memperbanyak regulasi yang mengatur tentang perlindungan anak, tetapi lebih dari itu memerlukan kebijakan dan langkah bersama Pemerintah dan lembaga pendidikan untuk meningkatkan upaya dalam memberikan perlindungan terhadap anak.

\section{DAFTAR REFERENSI}

Adioetomo, Sri Moertiningsih, dkk. 100 Tahun Demografi Indonesia: Mengubah Nasib menjadi Harapan. Cetakan Kedua. Jakarta: BKKBN dan LDFEUI, 2010.

Ahmad Kamil dan Fauzan. Hukum Perlindungan dan Pengangkatan Anak di Indonesia. Jakarta: PT RajaGrafindo Persada, 2008.

Ahmad Sofian, Januari 2017. "Legal Review Perlindungan Anak Di Indonesia," Artikel. Dimuat di http://business-law.binus.ac.id/2017/01/30/legal-review-perlindungananak-di-indonesia/ Diakses tanggal 20 Oktober 2018. 
Arliman S, Laurensius. "Partisipasi Masyarakat di dalam Perlindungan Anak yang Berkelanjutan sebagai Bentuk Kesadaran Hukum," Jurnal Ilmu Hukum, Volume 3, Nomor 2, 2016. ISSN 2460-1543.

, "Dinamika dan Solusi Perlindungan Anak di Sekolah." Jurnal Selat, Vol. 4 No. 2, Mei 2017. ISSN 2579-5767.

Catron, C.E. \& Allen, J. 2007. Early Childhood Curriculum A Creative-Play Model, 4th Edition. New York : Merill, Prentice-Hall.

Daisy Widiastuti, Rini Sekartini, Sari Pediatri, "Deteksi Dini, Faktor Risiko, dan Dampak Perlakuan Salah Terhadap Anak," Sari Pediatri, Vol. 7, No. 2, (September, 2005). ISSN 2338-5030.

Detik.com, https://news.detik.com/berita/d-3819079/miris-ibu-kandung-di-palembang-jualbayi-rp-20-juta-untuk-beli-sabu

, https://news.detik.com/berita-jawa-timur/d-3830088/ini-kesimpulan-polisi-usaiperiksa-ibu-yang-bunuh-3-anaknya?_ga=2.224627359.404968860.1531111802619765380.1521553471

Djamil, M. Nasir. Anak Bukan Untuk Dihukum. Jakarta: Sinar Grafika, 2013.

Ela, Nurhaidah, Intan, "Pemberian Punishment Yang Dilaksanakan Guru Di SD Negeri 4 Banda Aceh," Jurnal Ilmiah Pendidikan Guru Sekolah Dasar FKIP Unsyiah, Volume 2 Nomor 1, (12-21 Januari 2017)

Fakih, M, [penyunting]. Buku Panduan Pelatihan Deteksi Dini Dan Penatalaksanaan Korban Child Abuse And Neglect. Jakarta: IDI-UNICEF, 2003

Fitriani, Rini. "Peranan Penyelenggara Perlindungan Anak Dalam Melindungi Dan Memenuhi Hak-Hak Anak." Jurnal Hukum Samudra Keadilan, Volume 11, Nomor 2, Juli-Desember 2016. ISSN 1978-6395.

Garvey, Catherine, "The developing child series. Play (Enlarged ed.)" Paperback, 1 November 1990 (Cambridge, MA, US: Harvard University Press, 1990)

Kementerian Pemberdayaan Perempuan dan Perlindungan Anak (KPP-PA) Bekerjasama dengan Badan Pusat Statistik. Profil Anak Indonesia 2015. Jakarta: Kementerian Pemberdayaan Perempuan dan Perlindungan Anak (KPP\&PA). ISSN: 2089-3523.

Kementerian Pemberdayaan Perempuan dan Perlindungan Anak (KPP-PA). Strategi Nasional Penghapusan Kekerasan Terhadap Anak 2016-2020, 2015.

Kementerian Perencanaan Pembangunan Nasional/Badan Perencanaan Pembangunan Nasional. Rencana Aksi Nasional Perlindungan Anak 2015-2019. Jakarta: Kementerian Perencanaan Pembangunan Nasional/Badan Perencanaan Pembangunan Nasional, 2015.

Kompas Online, https://megapolitan.kompas.com/read/2018/02/05/ 05513961/anak-15tahun-di-bekasi-meninggal-diduga-dianiaya-orangtua. 
KPAI, "Data KPAI Update Per 24 Oktober 2016" [Pdf], diunduh tanggal 8 Oktober 2017 dari www.ucarecdn.com/2998b407-30a9-4949-ad65-7e6647bee610/

, "KPAI Nilai Sekolah Berperan Penting untuk Hentikan Bullying," 4 Oktober 2017. http://www.kpai.go.id/berita/kpai-nilai-sekolah-berperan-penting-untukhentikan-bullying/.

, "KPAI: 4.885 Kasus Pelanggaran Hak Anak, Terbanyak ABH," 8 Januari 2019. http://www.kpai.go.id/berita/kpai-4-885-kasus-pelanggaran-hak-anak-terbanyakabh.

Okezone.com, https://news.okezone.com/read/2018/03/06/337/1868702/5-9-juta-anakindonesia-jadi-pecandu-narkoba. Diakses pada tanggal 20 Oktober 2018.

Payne, Ruth."Using rewards and sanctions in the classroom: pupils' perceptions of their own responses to current behaviour management strategies," Journal Educational Review, Volume 67 (2015).

Purwanto, Ngalim. Ilmu Pendidikan Teoretis Dan Praktis. Bandung: PT Remaja Rosdakarya. 2011.

Republika Online, https://www.republika.co.id/berita/nasional/umum/18/03/06/ p55utk428kpai-sindikat-narkoba-mengincar-anak-berprestasi.

Soeroso, Moerti Hadiati. Kekerasan Dalam Rumah Tangga Dalam Perspektif Yuridis Viktimologis. Jakarta: Sinar Grafika, 2010.

Sujiono, Yuliani Nurani. Konsep Dasar Pendidikan Anak Usia Dini. Jakarta: PT Indeks, 2009.

Supeno, Hadi. Kriminalisasi Anak Tawaran Gagasan Radikal Peradilan Anak Terhadap Pemidanaan. Jakarta: Gramedia Pustaka, 2010.

Susanto, "Quo Vadis Perlindungan Anak di Sekolah: Antara Norma dan Realita," Rabu 20 Januari 2016, https://news.detik.com/kolom/3122977/quo-vadis-perlindungananak-di-sekolah-antara-norma-dan-realita.

Suyanto, Bagong. Masalah Sosial Anak. Jakarta: Kencana, 2010.

Tempo.co, " KPAI: Pelanggaran Hak Anak di 2018 Didominasi Tindak Kekerasan," 27 Desember 2018. https://nasional.tempo.co/read/1159391/kpai-pelanggaran-hakanak-di-2018-didominasi-tindak-kekerasan

Republik Indonesia, Undang-Undang Nomor 35 Tahun 2014 Tentang Perubahan Atas Undang-Undang Nomor 23 Tahun 2002 Tentang Perlindungan Anak.

Wagiati Sutedjo, 2010, Hukum Pidana Anak. Bandung: Refika Aditama, 2010.

Wahyudhi, Dheny. "Perlindungan Terhadap Anak Yang Berhadapan Dengan Hukum Melalui Pendekatan Restorative Justice," Jurnal Ilmu Hukum, Volume 6, No 1, Februari 2015. 